\title{
Is Corporate Social Responsibility an Agency Problem? Evidence from CEO Turnovers
}

May 2015

\begin{abstract}
We examine whether firms' Corporate Social Responsibility (CSR) activity is due to managers acting at the expense of their owners or in-line with owner preferences. The former implies that CSR activity is more prevalent among firms with entrenched managers, whereas the latter suggests that CSR activity is higher in firms with more vigilant owners. Consistent with the shareholder-driven view, our empirical results show that CEO turnover-financial performance sensitivity increases in firm CSR scores, measured contemporaneously as well as prior to CEO appointment. Further, CSR ratings remain unchanged following CEO turnover and are associated with measures of superior owner oversight.
\end{abstract}

Keywords: Corporate Social Responsibility, CEO turnover, Corporate Governance.

JEL classification: G34, L21, M51 


\section{Introduction}

We empirically examine the relation between firms' Corporate Social Responsibility (CSR) activity and the likelihood of their Chief Executive Officer's dismissal due to poor financial performance. ${ }^{1}$ The purpose of our empirical analysis is to test two competing hypotheses that are the subject of academic debate: is CSR due to poor firm governance, i.e. an agency problem between entrenched managers and firm owners, or because of owners' preferences for their firms' socially responsible activities (Benabou and Tirole, 2010)? Our examination of the relation between a firm's CSR ratings and the likelihood that its CEO is dismissed because of poor financial performance is premised on the argument that agency problems are more likely if a CEO is immune from the threat of removal (Hermalin and Weisbach, 1998).

An agency perspective implies that owners' inability to remove underperforming managers (poor firm governance) results in managers engaging in CSR activity from which they privately benefit at the expense of shareholders (Tirole, 2001; Pagano and Volpin, 2005; Cespa and Cestone, 2007; Benabou and Tirole, 2010). Consequently, firm CSR ratings are negatively associated with the likelihood that its CEO is dismissed in light of poor financial performance. In contrast, the owner preference perspective implies that higher CSR ratings are associated with superior oversight of management because it is shareholders that motivate managers to pursue CSR activities either because these activities increase long-term firm value or because of their desire to accommodate stakeholder preferences. Owners' greater emphasis on CSR activities in their manager's performance assessment is then accompanied with a concomitant increased emphasis on financial performance to prevent their manager from over allocating effort towards socially

\footnotetext{
${ }^{1}$ Publicly listed US firms expend significant resources on socially responsible initiatives such as providing generous employee benefits, supporting local communities and investing in clean technology. A survey by the Center for Corporate Citizenship (Boston College) found that, despite the financial crisis, in 2013 97\% of companies reported having an operating budget dedicated to corporate citizenship, compared to $81 \%$ in 2010 . Moreover, CSR reporting by firms has been increasing, with $93 \%$ of the world's top firms issuing sustainability reports in 2012/2013 according to KPMG's 2013 Survey of Corporate Responsibility Reporting. Additionally, CSR is playing an increasingly significant role in shaping consumers' preferences. A recent study by the Reputation Institute found that $89 \%(6 \%)$ of consumers are willing to recommend companies with excellent (poor) CSR ratings.
} 
responsible activities (Holmstrom and Milgrom, 1991). As a result, CSR ratings are positively associated with CEO turnover-financial performance sensitivity, when CSR activity is shareholder motivated.

Using a sample of public U.S. firms from 1996 to 2005 we examine the relation between performance induced (forced) CEO turnover and firm CSR ratings, by regressing CEO turnover on multiple dimensions of CSR as well as their interaction with firm stock returns. Our measures of CSR activity are the firm level ratings of corporate social performance by Kinder, Lydenberg and Domini Research and Analytics (KLD) that have been widely used in previous studies that examine CSR. KLD (now MSCI ESG Research) provides research, ratings and analysis of the environmental, social and governance-related business practices of companies. KLD provides firm-level annual scores of strengths and concerns related to seven CSR dimensions: community, corporate governance, diversity, employee relations, environment, human rights and product. Strengths measure proactive actions by firms to enhance their social performance (e.g. spousal benefits to same sex partners), whereas concerns reflect deficiencies related to social objectives (e.g. environmental failures). We measure each firm's CSR activity as each individual category's net score (strengths - concerns), aggregate strengths and concerns, as well as the aggregate net score across categories.

In a sample of 1,111 publicly listed US firms, we find that the likelihood of CEO dismissal due to poor financial performance, as measured by firm stock returns, increases in their firm's overall CSR rating in the years prior to the turnover as well as in the year prior to the previous CEO's departure. Moreover, the performance related CEO dismissal likelihood is increasing in CSR strengths that reflect proactive socially responsible activities by firms (e.g. family benefits to same-sex partners), but not in CSR concerns related to poor outcomes (e.g. employment discrimination lawsuit). In fact, for the subsample of firms with greater CSR concerns than strengths, CEO turnover is unrelated to financial performance. Our results are robust to the inclusion of managerial, firm and industry characteristics that past research has shown to affect executive turnover, and are both statistically and economically significant. A ten percent 
negative quarterly stock return increases CEO turnover likelihood by 1.1 percent for firms with net CSR scores of zero, and 1.94 percent for those with positive net CSR. Thus, our empirical results are inconsistent with the agency view of CSR and instead suggest that CSR is positively associated with effective firm governance.

We further examine whether CSR is associated with characteristics often associated with effective firm governance such as board size, CEO tenure, percentage of independent directors, CEO and director stock ownership, number of board meetings, the E- (entrenchment) index and number of board members on the corporate governance committee. We find that firm CSR ratings are positively associated with greater CEO and board ownership, board meeting frequency and lower E-index scores. We subsequently control for these firm governance characteristics and find that the conditional likelihood of CEO turnover due to poor financial performance increases in firm CSR ratings. Finally, we examine changes in firm CSR following CEO departure to determine whether CSR activities are a firm or managerial characteristic. We find that firms' CSR ratings do not significantly change post-CEO turnover in both univariate and multivariate tests that control for prior financial performance. This finding further supports the view that CSR is driven by owner preferences rather than by managers' personal preferences.

Our study makes several contributions to the existing empirical research that examines the economics of CSR. While the literature has largely focused on the relation between CSR and firm financial performance, it has yielded mixed results: some researchers find positive associations between CSR activity and firm value, whereas others show a negative relation or no significant association at all (see Deng et al., 2013 and Orlitzky et al., 2003; Margolis et al., 2007 for a review). Additionally, these studies are largely plagued with issues related to measurement horizon and reverse causality, i.e. the duration over which financial performance is measured and whether superior financial performance causes firms to invest in CSR activity. We avoid the causation issues that plague prior studies that examine the association between CSR and financial performance by examining the relation between CSR and the effectiveness of firm governance in mitigating agency problems. By examining if CSR is related to managerial 
entrenchment we are able to answer the crucial question of whether or not CSR is driven by agency concerns. Our results complement recent findings that the stock market reacts positively to increases in firm CSR ratings (Kruger, 2014). Further, our results suggest that shareholder preferences have a critical role in shaping CSR policy as well as in the corporate governance of firms; as such we provide evidence consistent with the strategic view of CSR proposed by Benabou and Tirole (2010).

The remainder of the paper is organized as follows: In Section 2, we develop our hypotheses concerning the relation between CSR and the likelihood of performance related CEO turnover. In Section 3, we provide details on the sample selection and provide descriptive statistics on our variables of interest. We discuss our empirical specification and results in Section 4. We describe several robustness tests of our results in Section 5. Finally, in Section 6 we conclude.

\section{CSR and executive turnover}

While CSR has acquired the reputation of being a catch-all phrase for an array of different concepts, theoretical views on its economic determinants can be broadly categorized into two competing visions of CSR: agency driven and shareholder driven. According to the agency driven view of CSR, CEOs engage in social projects for their own personal benefit as a way to build their reputation or to entrench themselves in the firm (Benabou and Tirole, 2010; Kitzmueller and Shimshack, 2012). Cespa and Cestone (2007) argue that incumbent CEOs under the threat of being replaced, strategically utilize CSR activities as an entrenchment strategy, i.e. by "buying off" company stakeholders. Pagano and Volpin (2005) provide a theoretical model in which top managers and lower level employees collude in order to entrench managers and avoid takeover threats. Specifically, high-level managers buy employee support by increasing employee benefits, which deters potential takeovers thereby lowering the likelihood of managerial turnover. 
Barnea and Rubin (2010) argue that top-managers over-invest in CSR activities in order to enhance their own personal reputations as good global citizens since the cost is borne by shareholders. Letza et al. (2004) provides an analytical framework called the "abuse of executive power" to explain this rent seeking behavior by firm managers. They state: "(the) major problem with current corporate governance arrangements are that they provide excessive power to executive managers who may abuse this power in pursuit of their own interests" (Letza et al., 2004, p. 245). In a similar note, Lavelle (2002) provides anecdotal evidence as to the use of philanthropic giving by CEOs to compromise the independence of influential directors on the board. Finally, Bartkus et al. (2002) argue that CSR (more specifically, corporate philanthropy) is associated with increases in agency problems. Collectively, these arguments are predicated on the view that firms' CSR activities are due to agency problems between owners and firms' managers.

CSR activities can potentially represent owner preferences for promoting good corporate citizenship in society due to idiosyncratic, "warm glow", preferences for socially desirable activities (Benabou and Tirole, 2010). The "warm glow" preferences for CSR are based on beliefs that shareholders derive utility from owning firms that are socially responsible (Kitzmueller and Shimshack, 2012). For example, owners prefer CSR to avoid the disutility from being connected to any socially stigmatized behavior related to their firm (e.g., firms using child labor or acting in an environmentally hazardous manner in production). This view is consistent with both shareholders endowed with preferences independent of their financial claims as well as those that only have social considerations in relation with their ownership. The former choose CSR because it is consistent with their general outlook, while the latter care about offsetting the negative social consequences of their firm's activities (Baron, 2007; Graff and Small, 2005).

Alternatively, a strategic view of CSR implies that shareholders believe that their long-term financial claims to firm assets are enhanced by firm CSR activities. Jensen (2001) argues that while value maximization should be the preeminent firm goal, CSR should not be viewed as an impediment to this goal since it is potentially a way to maximize shareholder wealth. Allen et al. 
(2014) propose that the governance arrangement of companies (shareholder or stakeholder oriented) affects their competitive behavior and outcomes in the product market and, as a consequence, their value. Specifically, their model predicts that, in cases where there is uncertainty regarding the industry's cost structure, stakeholder oriented companies perform better than their shareholder oriented counterparts. ${ }^{2}$ Under a shareholder driven view, both "warm glow" and strategic preferences imply that CSR is associated with active shareholder governance as opposed to a manifestation of agency problems between owners and managers.

Our hypotheses are premised on the notion that the likelihood of a CEO's performance related dismissal is reflective of owner oversight or governance over their firm's activities. Owners' oversight is critical since the separation of ownership and control in publicly held firms creates an opportunity for firm managers to extract private benefits from the firm (Alchian and Demsetz, 1972; Jensen and Meckling, 1976). One mechanism by which owners exercise their oversight is by replacing their CEO in light of poor firm performance. A large literature examining CEO turnover documents a significant association between forced CEO turnover and firm stock and accounting performance (Warner et al., 1988; Kaplan and Minton, 2008). Recent work has extended this line of inquiry to show that "strong" boards are more likely to dismiss their CEO following poor financial performance than are "weak" boards (Defond and Hung, 2004; Jenter and Lewellen, 2010). The upshot of these findings is that the likelihood of CEO turnover due to firm performance is indicative of owners' governance of firm operations, i.e. CEOs of better governed firms are more likely to be dismissed for poor financial performance than their counterparts at poorly governed firms.

We use this insight to determine whether firms' corporate socially responsible activities are driven by managerial actions to gain private benefits (agency driven) or because such activities are consistent with owner preferences (shareholder driven). Specifically, we offer two competing

\footnotetext{
${ }^{2}$ Edmans (2011), Derwall et al. (2005), Flammer (2013) provide evidence regarding the mechanisms through which CSR can enhance shareholder wealth, while Statman and Glushkov (2009), Kempf and Osthoff (2007), and Eccles et al. (2012) provide empirical evidence on the relation between CSR and financial performance.
} 
hypotheses. The agency-driven CSR predicts that firms with higher CSR scores are weakly governed and their CEOs are less likely to be removed in light of poor firm financial performance. Consequently, CEO turnover-financial performance relation is negatively associated with CSR because entrenched managers engage in such activities to extract private control benefits and "weak" firm governance reduces their likelihood of dismissal (Pagano and Volpin, 2005; Cestone and Cespa, 2007). Conversely, the shareholder-driven CSR hypothesis predicts that the CEO turnover-financial performance relation increases in firm CSR scores. Owners that value their firm's CSR scores emphasize these activities in assessing CEO performance, but also increase their emphasis and oversight on financial performance to prevent over allocation of CEO attention to socially responsible tasks. The increased emphasis on financial performance is an implication of the Holmstrom and Milgrom (1991) multi-tasking principal agent model. If two activities are substitutes in the production function (e.g. enhancing financial performance and CSR) and the agent has limited attention, emphasizing only one activity (CSR) results in under allocation of effort towards the other (financial performance). Consequently, a principal desiring to motivate an agent to engage in CSR activity must also increase the emphasis on financial performance. ${ }^{3}$ This implies that owners of firms with higher CSR scores are more likely to remove their CEOs in light of poor financial performance.

\section{Data and research design}

In this section, we discuss the variables, sample and data characteristics. We also present descriptive statistics and our univariate analysis of the relation between CSR and CEO performance related turnover.

\footnotetext{
${ }^{3}$ A necessary condition for this prediction is that CSR activity measures are informative and reliable. Research by Godfrey et al. (2009) and Kruger (2014) attests to the informativeness and economic significance of the KLD measures of CSR that we employ in our empirical tests.
} 


\subsection{Sample selection and data sources}

We construct our sample with data from several sources. We obtain firm-level CSR scores from KLD for the years 1996 to 2005. KLD is an information intermediary that provides ratings for firms' corporate social performance to investors, screening close to 3,000 firms. ${ }^{4}$ KLD provides narrative coverage of firm performance along community, diversity, employee relations, environment, human rights, corporate governance, and product dimensions. KLD data has been widely used in previous studies (see, among others, Harrison and Freeman, 1999; Johnson and Greening, 1999; McWilliams and Siegel, 2000; Godfrey et al., 2009; Kruger, 2014) and represents one of the most reliable sources of information on firms' social performance. ${ }^{5} \mathrm{We}$ utilize the KLD coverage sample as our base given the need for CSR scores in our empirical tests.

Using the data provided by KLD, we construct our measures of CSR for each firm. Firms are rated on their strengths (such as: generous employee benefits or board diversity) and concerns (such as: employee disputes or substantial emissions) within each of the categories. To construct our first measure of CSR we subtract each firm's total concerns from their total strengths, aggregated across categories, obtaining a net overall performance score for each firm year. In addition to the net scores, we utilize separately the sum of total strengths and total concerns across the various categories to identify potential nonlinearities between the effects of total strengths versus those of total concerns.

We merge our KLD database with Execucomp, which provides information on CEO start and termination dates allowing us to identify CEO turnovers by quarter. Following Dikolli et. al. (2009), we classify CEO turnovers as forced and unforced based on press releases around announcements. We conduct our tests using only forced CEO turnovers because not all CEO

\footnotetext{
${ }^{4}$ The KLD database covers companies listed on the S\&P 500 from 1992 as well as the full Russell 1000 from 2002 onward.

${ }^{5}$ For a detailed discussion of KLD's framework see Sharfman (1996).
} 
changes are performance related: some may leave voluntarily because of retirement, or due to personal circumstances, such as health reasons or death. We conduct our analysis on a sample of 599 forced turnovers spanning the years 1996 to $2005 .{ }^{6}$ Monthly stock returns and fiscal quarter end stock price data are obtained from the Center for Research in Security Prices (CRSP) and quarterly accounting data is gathered from Compustat. Our measures for the number of board meetings, CEO and director ownership, board size, number of independent directors, and number of board members in the corporate governance committee are obtained from the Institutional Investors Research Center database, via Institutional Shareholders Service.

Unlike previous studies, we follow Dikolli et al. (2009) and use both quarterly and annual data in our empirical tests. This design allows us to obtain more precise measures of firm performance with which to match CEO turnovers than those available annually. Both Compustat and CRSP data are available at the end of each firm's fiscal quarter. KLD, Execucomp and IRRC data, which are only available on an annual basis, are matched to fiscal quarters by taking the fiscal year end values for each variable and applying those to each of the fiscal quarters in that year. Lack of CSR and firm governance variables on a quarterly basis potentially introduces error in our measures but we do not believe that the error is systematically correlated with the likelihood of CEO turnover. We measure firm performance as the industry-adjusted quarterly stock return (Returns) for a firm, which has been commonly used in prior literature (Brickley, 2003; Dikolli et al., 2009). Our final sample consists of 21,435 firm-quarter observations from 1996 to 2005, corresponding to 1,111 firms.

\subsection{Descriptive statistics}

Table 1 displays descriptive statistics for sample firms. Our dependent variable, CEO turnover, is an indicator variable equal to one in the quarter in which there is a forced CEO change and zero otherwise. The unconditional quarterly forced CEO turnover rate in our sample is $2.8 \%$. The

\footnotetext{
${ }^{6}$ Our sample begins in 1996 because the governance data that we utilize in our test is only available beginning in 1996.
} 
average cumulative median industry adjusted stock return over the prior four quarters for sample firms is $3.5 \%$ with a median return of $2.1 \%$.

Prior studies have shown that performance measure variability is inversely related to the likelihood of performance related turnovers (Engel et al., 2003). As a result, we include return volatility measured as the cumulative density function of the standard deviation of the firm's monthly change in stock price over the prior 60 months in our tests. The average for this measure in our sample is -0.321 . To control for firm growth opportunities that affect the CEO turnover likelihood we also include each firm's book to market ratio. The average book to market ratio in our sample is 0.623 . Firms in our sample have average log sales of 7.938 and average log assets of 8.790. We further control for managerial characteristics that are associated with turnover likelihood by using CEO age, a variable indicating whether the CEO is close to retirement age as well as CEO tenure. Table 1 shows that the average CEO in the sample is 57 years old and the average (median) CEO tenure are 7.32 (4.89) years. Only 6.7\% of sample CEOs are at retirement age. We partition our sample based on median tenure to conduct some of our robustness tests given prior findings that tenure moderates the CEO turnover-financial performance relation (Dikolli et al., 2009). Our firm governance variables reflect board composition and ownership of the firm by executives and directors. The mean firm in the sample has 10 directors on its board, with $68 \%$ of them independent and holding on average $8.3 \%$ of their firm's outstanding shares. The boards meet on average 7 times a year and the median firm's corporate governance committee has 3 members.

In Table 2 we provide univariate correlations between CEO turnover, returns, board size, CEO tenure and our CSR variables. Tabulated results show that turnover is positively correlated with board size, CEO tenure, CSR net, CSR strengths and CSR concerns, while being significantly negatively correlated with returns. Overall, these results suggest that CEO turnover and CSR are positively related unconditionally. The following empirical tests examine this relation conditional on firm performance. 


\section{Empirical design and results}

We follow Dikolli et al. (2009) and run the following baseline logistic regression specification to estimate the determinants of CEO turnover, augmented with our firm-level CSR measures:

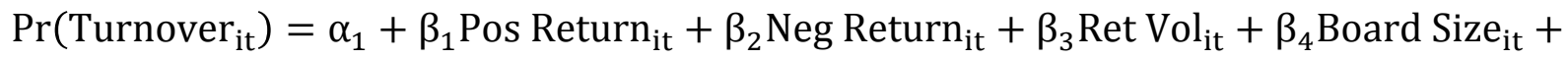

$$
\begin{aligned}
& \beta_{5} \text { Ind Dir Perc }_{\text {it }}+\beta_{6} \text { Age }_{i t}+\beta_{7} \text { Retire Age }_{i t}+\beta_{8} \text { Assets }_{i t}+\beta_{9} \text { BTM }_{i t}+ \\
& \beta_{10} \mathrm{CSR}_{\mathrm{it}}+\beta_{11} \mathrm{CSR} * \text { Neg Return } \text { it }+\epsilon_{\mathrm{it}}
\end{aligned}
$$

Since forced turnovers are more likely driven by poor performance, we enhance the power of our tests by allowing for asymmetric effects and include separately both positive and negative stock returns. CSR and the interactive effect between CSR and poor firm performance, CSR*Neg Return, are our variables of interest. In our tests, we vary the definition of CSR depending on the dimension measured.

Table 3 - Panel A reports the results from estimating our empirical specification. The baseline model in Model 1 is consistent with prior studies on CEO turnover (Dikolli et al., 2009), as the coefficient on negative returns is negative and significant and the coefficient on positive returns is negative and insignificant, confirming the asymmetry between positive and negative returns on forced CEO turnover. Also consistent with prior work, the coefficients on returns volatility, board size, and CEO age are all positive and significant. The coefficient on the book to market ratio is negative and significant, consistent with lower turnover likelihood for CEOs of larger and more mature firms. CSR, which we measure as the net CSR score of the firm, is unrelated to CEO turnover unconditionally, but the coefficient on the interaction of CSR with negative returns is negative and significant. Thus, CEOs of firms with higher CSR scores are more likely to be replaced following poor firm financial performance than their counterparts at firms with lower CSR scores.

In Model 2 of Table 3 - Panel A, we measure CSR as the firm's CSR score under the previous $\mathrm{CEO}$ and we also include the change in firm CSR score between the current and the previous 
CEO's appointment. ${ }^{7}$ As the CSR of the previous CEO is out of the current CEO's control, it allows us to rule out the agency-driven CSR as alternative explanation of our main result. Model 2 shows that the interaction variable, when measured as the firm's CSR score during the previous CEO's appointment, remains significant and negative. This result reinforces the prior finding that the positive relationship between CEO turnover and CSR is due to better firm governance rather than agency problems.

In Model 3 of Table 3 - Panel A we substitute the CSR Net score with an indicator variable equal to one if a firm's net CSR rating is greater than zero and interact it with negative returns. In doing so, we examine the effect of high levels of CSR on the turnover performance relation. Consistent with our previous results, we find that in high CSR firms the CEO turnover-financial performance sensitivity significantly increases, indicating better governance.

Given our original logistic specification that includes interactive terms we are unable to interpret the economic magnitude of the interaction coefficient. Consequently, in Table 3 - Panel B we run our base line model over three subsamples: firms with CSR net score less than zero (Model 1); firms with CSR net score equal to zero (Model 2); firms with CSR net score greater than zero (Model 3), to examine the changes in the marginal effect of negative returns on CEO turnover across the samples. Results suggest an increase in the marginal effects of negative performance on the turnover sensitivity across the samples. Negative returns do not have any significant impact on CEO Turnover in companies with CSR Net less than zero, while they have a significant impact in the sample where CSR Net is equal to zero (marginal coefficient: -0.110 ) and even more so in the sample where CSR Net is greater than zero (marginal coefficient: 0.194). The turnover probability given negative performance increases from 1.10 percent, in the zero CSR sample, to 1.94 percent, in the high CSR sample, representing more than a 75 percent increase in the magnitude of the effect.

\footnotetext{
${ }^{7}$ We lose 91 (of 599) CEO turnover observations for which the firm CSR rating in the last year of the previous CEO is not available.
} 
We examine whether CSR asymmetrically effects the CEO turnover-financial performance relation by separating the net score into CSR strengths and CSR concerns. Strengths correspond largely to proactive actions by firms, whereas concerns reflect deficiencies. In Table 4 - Model 1 we show that CSR strengths drive our results, as the interaction between CSR strengths and negative returns is significant and negative. Conversely, in Model 2, which includes the interaction between CSR concerns and negative returns, we find that CSR concerns do not significantly impact the CEO turnover-financial performance relation. In Model 3, which includes both strengths and concerns, we see that the interaction between CSR strengths and negative returns remains significant while CSR concerns do not play a significant incremental role in explaining performance-related CEO turnovers. Finally, in Model 4 and 5 we replace CSR strengths and concerns with those of the previous CEO, in order to rule out the possibility of the agency-driven CSR explaining our main result. In Model 4, we find that the interaction variable between CSR strength and negative returns is still significant, consistent with the interpretation of CSR scores representing good governance. In Model 5, CSR Concerns is significant and negative but when interacted with negative returns it is insignificant.

Collectively, Tables 3 and 4 suggest that higher levels of CSR increase the likelihood that a CEO is dismissed for poor firm performance. This positive association is more indicative of CSR being driven by shareholder preferences, i.e. good governance, rather than by agency problems that imply a negative association between the CEO turnover-performance relation and CSR.

\section{Robustness and sensitivity analysis}

While our results in the previous section are consistent with the shareholder-driver view of CSR, rather than the agency view, in this section we examine their robustness to the inclusion of additional firm characteristics. Specifically, we examine whether firms' observable corporate governance attributes are associated with CSR ratings, whether CSR ratings incrementally explain the CEO turnover-performance relation, and how CEO turnover affects firm CSR ratings. 


\subsection{Corporate governance attributes between high and low CSR firms}

In Table 5 we examine differences in the governance characteristics of firms with CSR scores less than zero, equal to zero, and greater than zero. In particular, we examine whether high CSR (net CSR greater than zero) and low CSR (net CSR less than zero) differ in the following governance attributes: board size, CEO tenure, percentage of independent directors, CEO age, the percentage of voting power held by the board excluding the CEO, number of board meetings, size of the corporate governance committee, book to market ratio, sales (log), assets (log), shares held by CEO (\%) and the Entrenchment Index (E-Index) introduced by Bebchuk et al. (2009). If CSR were driven by an agency problem we would expect that high CSR firms display "weaker" corporate governance than their low CSR counterparts. Our univariate results in Table 5 show that high CSR firms have significantly larger boards, greater director voting rights, larger corporate governance committee, and higher CEO ownership. High CSR firms are also larger and have lower book to market ratios. Finally, high and low CSR firms do not differ significantly in CEO tenure, board independence, number of board meetings and E-Index. Overall, high CSR firms seem to exhibit "stronger" corporate governance attributes rather than "weaker" governance characteristics as would be predicted by the agency driven view of CSR.

\subsection{CSR and CEO turnover controlling for governance characteristics}

While our main tests show that CSR increases the CEO turnover-financial performance relation, this is potentially driven by firms' governance choices that are correlated with both CSR and increases in CEO turnover-financial performance sensitivity. Since CSR scores are, in fact, associated with firm governance choices, we examine whether the variation in CSR that is unexplained by firm governance choices affects the relation between firm performance and CEO turnover. ${ }^{8}$

\footnotetext{
8 In concurrent work, Cheng et al. (2013) test the agency driven view of CSR using the 2003 Dividend Tax Cut. They find that firms with intermediate managerial ownership decreased CSR after the 2003 Dividend Tax Cut reflecting an increase in relative CEO ownership and a reduction in agency problems. We address this issue by using CEO ownership as a determinant of CSR.
} 
In order to isolate the CSR component related to firm governance characteristics, we run a determinants model of CSR net, CSR strengths and CSR concerns using an OLS regression controlling for firm size, CEO and director shareholding, board size, industry, and year fixed effects. We use the predicted CSR from the model as our measure of CSR determined by firm governance choices and the residual as the unexplained CSR. Table 6 - Panel A reports the results of using the predicted and residual CSR and their interactions with negative returns as determinants of CEO turnover. Results of the specification in Model 1 shows that only the coefficient on the interaction between the residual CSR and negative returns is significant in explaining performance related CEO turnover while the coefficient on predicted CSR and its interaction is not significant. Model 2, which uses the predicted and residual components of CSR strengths, also confirms that the residual and its interaction significantly predict financial performance related CEO turnover while the predicted value does not. Finally in Model 3, where the CSR concerns score is used, both the predicted and residual CSR and their interactive effects are insignificant in predicting performance related CEO turnover. Overall, these results are consistent with CSR having a positive effect on CEO turnover-financial performance sensitivity independent of firm governance characteristics and as such further supports the view that CSR scores reflect shareholder preferences rather than agency problems between managers and owners.

Dikolli et al. (2009) find that the negative relation between CEO turnover and firm performance monotonically declines in CEO tenure, consistent with firm performance revealing information about a CEO's uncertain ability to increase firm value over time. We use this insight to enhance the power of our empirical tests. Specifically in Table 6 - Panel B we rerun our baseline model over samples of low (Model 1) and high (Model 2) tenured CEOs. We find that the interactive effect of CSR and negative returns is significant and negative in the low tenure sample and insignificant in the high tenure sample. This is consistent with the impact of CSR being stronger on lower tenured CEOs whose ability is more uncertain and as such their performance carries a significant weight on the turnover decision while for high tenured CEOs whose ability is more 
certain due to their experience, CSR does not incrementally affect the turnover performance sensitivity.

\subsection{CEO turnover and changes in CSR}

To shed further light on whether firms' CSR activities are a managerial or firm characteristic we investigate the changes in firms' CSR ratings around turnover years and compare them with changes in non-turnover years. In order to reduce measurement error in our change measures we take the two-year average before and after each turnover for comparison. In conducting this analysis, we are able to examine whether a CEO affects the CSR score using the turnover as the event, consequently changes in CSR reflect an incoming CEO's influence on CSR. The agency view predicts that the change is significantly negative in turnover years as compared to nonturnover years since the outgoing CEO was likely dismissed for over investing in socially responsible activities. In Table 7 - Panel A we address this by comparing the changes in firm CSR scores between CEO turnover years and non-turnover years along the various categories. Results show that there is no significant difference between changes in Net CSR around turnovers as compared to non-turnover years.

While univariate results support the shareholder driven view of CSR, the effect of CEO turnover is potentially confounded with the effect of past negative performance that led to executive departure. In Table 7 - Panel B we run a logistic regression of an indicator variable set to one when the change in CSR is greater than zero and zero when the change in CSR is less than zero as the dependent variable. We do this for CSR net, CSR strengths and CSR concerns. We regress these indicator variables on a negative return indicator variable, set to one when returns are negative, a CEO turnover indicator variable, the interaction between CEO turnover and the negative returns indicator variable, and the change in log firm assets. We additionally control for year and industry fixed effects. Results indicate that CEO turnover does not affect changes in CSR. Additionally, the interaction between CEO turnover and negative firm returns is insignificant. We interpret this evidence as inconsistent with the notion that CSR is a managerial 
choice rather than a firm characteristic. By examining CSR around CEO turnovers we are able to disentangle managerial effects from firm effects, thus overcoming limitations of previous studies that rely on cross-sectional tests. We conclude that CSR activities are unlikely to be driven by managers and largely reflect firm owners' choices.

\section{Conclusion}

Despite the prevalence and economic significance of Corporate Social Responsibility activities, firms' motives for engaging in such activities remain the subject of great academic debate (Margolis et al., 2007; Benabou and Tirole, 2010). Amongst this debate two broad views of CSR have emerged: the agency driven view and shareholder driven view. Proponents of the agency perspective view CSR as being driven by CEOs who engage in social projects for their own private benefit as a way to build their reputation or to entrench themselves in the firm, thereby adversely affecting shareholder value (Benabou and Tirole, 2010; Kitzmueller and Shimshack, 2012). In contrast, the shareholder perspective implies that it is owners that motivate their firm's manager to pursue CSR activities either to increase the value of their financial claims or to accommodate their non-monetary preferences.

In this paper, we examine the relation between CSR and firms' governance quality. Specifically, we examine the effect of a firm's CSR rating on the likelihood that its CEO is dismissed due to poor financial performance. A large literature, premised on the notion that agency problems are more likely if a CEO is entrenched, has shown that the likelihood of CEO performance-related dismissal is indicative of firm-level governance (Hermalin and Weisbach, 1998). We use this insight to determine whether CSR activity is a result of poor governance, i.e. an agency problem between owners and managers, or rather reflects owners' preferences. We find that the likelihood of CEO dismissal due to poor financial performance, as measured by firm stock returns, is increasing in the firm's overall CSR rating, measured both in the departing CEO's last year as well as in the last year of the previous CEO's appointment. Moreover, the performance related dismissal likelihood is increasing in CSR strengths that reflect proactive socially responsible 
activities by firms (e.g. family benefits to same-sex partners), but not in CSR concerns that largely reflect poor outcomes (e.g. employment discrimination lawsuit).

Our results remain robust to the inclusion of firm governance characteristics such as board size, CEO tenure, percentage of independent directors, CEO age, CEO and director ownership, number of board meetings, and number of board members on the corporate governance committee. We document that high CSR firms are associated with better firm governance; however, even after controlling for these characteristics, firm CSR ratings are positively related to CEO turnover-financial performance sensitivity. Finally, we examine the influence of the CEO on the CSR activities of the firm by examining differences in firm CSR ratings around turnovers. We find that firm CSR scores do not change around turnovers when compared to nonturnover years. This finding corroborates the view that CSR is driven by shareholder preferences rather than by managers' personal preferences.

We contribute to the literature by relating CSR to the effectiveness of the firm's corporate governance, thereby abstracting from the shortcomings of previous studies that examine the association between CSR and financial performance. By examining if CSR is reflective of good governance we are able to answer the question of whether CSR is driven by an agency problem. This has the advantage of addressing an important question without the empirical problems related to reverse causality and measurement horizon inherent in CSR-financial performance association studies. 


\section{References}

Alchian, A.A., Dsemsetz, H., 1972. Production, information costs and economic Organization. American Economic Review 62, 777-795.

Allen, F., Carletti, E., Marquez, R., 2014. Stakeholder governance, competition and firm value. Review of Finance 18(1), 1-32.

Barnea, A., Rubin, A., 2010. Corporate social responsibility as a conflict between shareholders. Journal of Business Ethics 97, 71-86.

Baron, D.P., 2007. Corporate social responsibility and social entrepreneurship. Journal of Economics \& Management Strategy 16(3), 683-717.

Bartkus, B.R., Morris, S.A., Seifert, B., 2002. Governance and corporate philanthropy: Restraining Robin Hood? Business \& Society 41(3), 319-344.

Bebchuk, L., Cohen, A., Ferrell, A., 2009. What matters in corporate governance? The Review of Financial Studies 22(2), 783-827.

Benabou, R., Tirole, J., 2010. Individual and corporate social responsibility. Economica 77(305), 1-19.

Brickley, J.A., 2003. Empirical research on CEO turnover and firm-performance: a discussion. Journal of Accounting and Economics 36(1-3), 227-233.

Cespa, G., Cestone, G., 2007. Corporate social responsibility and managerial entrenchment. Journal of Economics and Management Strategy 16, 741-77.

Cheng, I.H., Hong, H., Shue, K., 2013. Do managers do good with other people's money? Unpublished working paper. National Bureau of Economic Research.

Defond, M, Hung, M., 2004. Investor protection and corporate governance: Evidence from worldwide CEO turnover. Journal of Accounting Research 42(2), 269-312.

Deng, X., Kang, J., Low, B.S., 2013. Corporate social responsibility and stakeholder value maximization: Evidence from mergers. Journal of Financial Economics 110, 87-109.

Derwall, J., Guenster, N., Bauer, R., Koedijk, K., 2005. The eco-efficiency premium puzzle. Financial Analysts Journal 61, 51-63. 
Dikolli, S.S., Mayew, W.J., Nanda, D., 2014. CEO Tenure and the performance-turnover relation. Review of Accounting Studies 19, 281-327.

Eccles, R.G., Ioannou, I., Serafeim, G., 2012. The impact of a corporate culture of sustainability on corporate behavior and performance. Unpublished working paper. Harvard Business School.

Edmans, A., 2011. Does the stock market fully value intangibles? Employee satisfaction and equity prices. Journal of Financial Economics 101, 621-640.

Engel, E., Hayes, R.M., Wang, X., 2003. CEO turnover and properties of accounting information. Journal of Accounting and Economics 36(1-3), 197-226.

Flammer, C., 2013. Corporate social responsibility and shareholder reaction: The environmental awareness of investors. Academy of Management Journal 56, 758-781.

Godfrey, P.C., Merrill, C.B., Hansen, J.M., 2009. The relationship between corporate social responsibility and shareholder value: An empirical test of the risk management hypothesis. Strategic Management Journal 30, 425-445.

Graff, Z.J., Small, A., 2005. A Modigliani-Miller theory of altruistic corporate social responsibility. Topics in Economic Analysis \& Policy 5(1), 1-19.

Harrison, J.S., Freeman, R.E., 1999. Stakeholders, social responsibility, and performance: Empirical evidence and theoretical perspectives. Academy of Management Journal 42(5), 479485.

Hermalin, B.E., Weisbach, M.S., 1998. Endogenously chosen boards of directors and their monitoring of the CEO. The American Economic Review 88(1), 96-118.

Holmstrom, B., Milgrom, P., 1991. Multitask principal agent analyses--Incentive contracts, asset ownership, and job design. Journal of Law, Economics, and Organization 7, 24-52 (Special Issue).

Jensen, M.C., 2001. Value maximization, stakeholder theory, and the corporate objective function. European Financial Management Review 7(3), 297-317.

Jensen, M.C., Meckling, W.H., 1976. Theory of the firm: Managerial behavior, agency costs and ownership structure. Journal of Financial Economics 3(4), 305-360.

Jenter, D., Lewellen, K., 2010. Performance-induced CEO turnover. Unpublished working paper. Stanford University. 
Johnson, R.A., Greening, D.W., 1999. The effects of corporate governance and institutional ownership types on corporate social performance. Academy of Management Journal 42, 564576.

Kaplan, S., Minton, B., 2008. How has CEO turnover changed? Increasingly performance sensitive boards and increasingly uneasy CEOs. Unpublished working paper. Ohio State University.

Kempf, A., Osthoff, P., 2007. The effect of socially responsible investing on portfolio performance. European Financial Management 13, 908-922.

Kitzmueller, M., Shimshack, J., 2012. Economic perspective on corporate social responsibility. Journal of Economic Literature 50(1), 51-84.

Kruger, P., 2014. Corporate goodness and shareholder wealth. Journal of Financial Economics (forthcoming).

Lavelle, L., 2002. Enron: How governance rules failed. Business Week, 28-29.

Letza, S., Sun, X., Kirkbride, J., 2004. Shareholding versus stakeholding: A critical review of corporate governance. Corporate Governance: An International Review 12(3), 242-262.

McWilliams, A., Siegel, D., 2000. Corporate social responsibility and financial performance: Correlation or misspecification? Strategic Management Journal 21(5), 603-609.

Margolis, J., Elfenbein, H., Walsh, J., 2007. Does it pay to be good? A meta-analysis and redirection of research on the relationship between corporate social and financial performance. Unpublished working paper. University of Michigan.

Orlitzky, M., Schmidt, F., Rynes, S.L., 2003. Corporate social and financial performance: a meta-analysis. Organization Studies 24, 403-441.

Pagano, M., Volpin, P.F., 2005. Managers, workers, and corporate control. Journal of Finance 60(2), 841-868.

Sharfman, M., 1996. The construct validity of the Kinder, Lydenberg \& Domini social performance ratings data. Journal of Business Ethics 15(3), 287-296. 
Statman, M., Glushkov, D., 2009. The wages of social responsibility. Financial Analysts Journal $65,774-800$.

Tirole, J., 2001. Corporate governance. Econometrica 69(1), 1-35.

Warner, J., Watts, R., Wruck, K., 1988. Stock prices, event prediction and event studies: An examination of top management restructurings. Journal of Financial Economics 20, 461-492. 
Table 1

Descriptive Statistics

This table reports descriptive statistics for the variables used in our analyses. We report the mean, standard deviation and values of the interquartile range for the following variables: CEO Turnover is an indicator variable equal to one in the quarter in which a forced CEO change occurs and zero otherwise. Returns are the cumulative median-industry-adjusted (2digit SIC) mothly stock returns computed from CRSP for the four quarters immediately preceding the turnover quarter, or if the CEO was employed for less than four quarters, the cumulative returns over the CEO's tenure. Industry values are calculated from all available monthly observations of sample firms. Returns volatility is the cumulative density function of the standard deviation of firm's monthly change in stock price over the prior 60 months. Missed Earnings is the sum of the number of the negative quarterly surprises, measured as the number of negative quarterly analyst forecast errors, or quarterly earnings decreases relative to the same quarter of the prior year over the four quarters immediately preceding the quarter. For CEOs employed for less than four quarters, we count the number of surprises over the CEO's tenure. Board Size is the number of directors on the firm's board of directors. Independent Directors (\%) is the percentage of independent directors on the firm's board. CEO Age is the age of the CEO, in years, as of the quarter immediately prior to the quarter. CEO Tenure is the number of years as CEO of the firm. Retirement Age CEO is an indicator variable equal to one if CEO age equals 64, 65 or 66 years, zero otherwise. Book to Market Ratio is the firm's book value of equity divided by its market value of equity at fiscal quarter end. Sales $(\log )$ is the logarithm of sales. Assets (log) is the logarithm of assets. Voting power held by board excluding CEO (\%) is the percentage of voting power held by the board not including the CEO shares. Shares held by CEO (\%) is the percentage of voting power held by CEO. Number of Board Meetings is the number of meetings held by the board during the year. Number of Board Members on C.Gov Committee is the number of members in the corporate governance committee of the board. CSR Strengths is the sum of the total strengths for a firm across all categories of CSR, as reported by KLD. CSR Concerns is the sum of the total concerns for a firm across various categories of CSR. CSR Net is the difference between a firm's total strengths and total concerns. All variables are winsorized at the $1 \%$ and $99 \%$ level.

\begin{tabular}{|c|c|c|c|c|c|c|}
\hline Variable & $\mathrm{N}$ & Mean & $\begin{array}{c}\text { Standard } \\
\text { Deviation }\end{array}$ & $\begin{array}{c}1 \text { st } \\
\text { Quartile }\end{array}$ & Median & $\begin{array}{c}\text { 3rd } \\
\text { Quartile }\end{array}$ \\
\hline CEO Turnover & 21,435 & 0.028 & 0.001 & 0 & $\overline{0}$ & 0 \\
\hline Returns & 21,424 & 0.035 & 0.287 & -0.121 & 0.021 & 0.176 \\
\hline Returms volatility & 20,316 & -0.321 & 0.889 & -1.082 & -0.420 & 0.350 \\
\hline Missed Earnings & 21,435 & 0.66 & 1.369 & 0 & 0 & 1 \\
\hline Board Size & 21,435 & 10.324 & 2.758 & 8 & 10 & 12 \\
\hline Independent Directors (\%) & 21,435 & 0.681 & 0.158 & 0.571 & 0.7 & 0.8 \\
\hline CEO Age & 21,337 & 57.08 & 6.95 & 52 & 57 & 61 \\
\hline CEO Tenure & 21,435 & 7.322 & 7.475 & 2.164 & 4.898 & 9.753 \\
\hline Retirement Age CEO & 21,361 & 0.067 & 0.251 & 0 & 0 & 0 \\
\hline Book to Market Ratio & 21,412 & 0.623 & 0.254 & 0.423 & 0.631 & 0.836 \\
\hline Sales $(\log )$ & 21,426 & 7.938 & 1.366 & 6.974 & 7.872 & 8.868 \\
\hline Assets $(\log )$ & 21,427 & 8.790 & 1.593 & 7.095 & 8.671 & 0.924 \\
\hline Voting power held by board excl. CEO (\%) & 19,346 & 8.317 & 18.456 & 0.007 & 1.708 & 7.362 \\
\hline Shares held by CEO $(\%)$ & 21,435 & 2.766 & 6.415 & 0 & 0.31 & 1.91 \\
\hline Number of Board Meetings & 6,842 & 7.167 & 2.885 & 5 & 7 & 8 \\
\hline Number of Board Memb on C.Gov Comm & 18,611 & 2.798 & 2.276 & 0 & 3 & 4 \\
\hline CSR Strengths & 21,435 & 1.972 & 2.211 & 0 & 1 & 3 \\
\hline CSR Concerns & 21,435 & 1.943 & 2.096 & 1 & 1 & 3 \\
\hline CSR Net & 21,435 & 0.798 & 3.147 & -1 & 0 & 2 \\
\hline
\end{tabular}


Table 2

Correlation Matrix

This table displays the Pearson pairwise correlations among our main variables of interest for our sample, which is composed of 20,227 firm-quarter observations. We show the correlation between CEO Turnover, Returns, Board Size, CEO Tenure, CSR Net, CSR Strengths and CSR Concerns. All variables are winsorized at the $1 \%$ and $99 \%$ level.

Levels of significance are indicated by: $* \mathrm{p}<0.10,{ }^{* *} \mathrm{p}<0.05, * * * \mathrm{p}<0.01$

Variable

(1)

(2)

(3)

(4)

(5)

(8)

(9)
CEO Turnover

Returns

Board Size

CEO Tenure

CSR Net

CSR Strengths

CSR Concerns
1

$-0.047 * * * \quad 1$

$0.029 * * * \quad-0.053$

$0.088 * * * \quad 0.024 * * * \quad-0.039 * * * \quad 1$

$0.012 * 0.007 \quad 0.172 * * * \quad-0.045 * * * \quad 1$

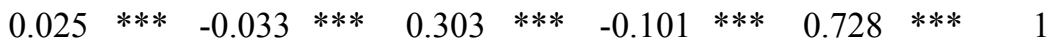

$\begin{array}{lllllllllll}0.033 & * * * & -0.056 & * * * & 0.215 & * * * & -0.101 & * * * & -0.271 & * * * & 0.351\end{array}$

$* * * \quad 1$ 
Table 3 - Panel A

Effect of Corporate Social Responsibility on CEO Turnover Performance Sensitivity

This table analyzes the determinants of CEO Turnover, which is the dependent variable. Our main variable of interest is the interaction between CSR and Negative Returns. All variables are winsorized at the 1\% and 99\% level. Standard Errors are clustered by firm and are reported in parenthesis. Margins are reported in square brackets. Model (1) is run over the full sample; Model (2) measures CSR as the CSR score of the previous CEO, which is out of the control of the current CEO; Model (3) measures CSR as an indicator variable which is set to 1 if CSR net $>0$, to 0 if CSR net $<0$, and missing if CSR net $=0$.

Levels of significance are indicated by: $* \mathrm{p}<0.10, * * \mathrm{p}<0.05, * * * \mathrm{p}<0.01$

\begin{tabular}{|c|c|c|c|c|c|c|}
\hline Variable & \multicolumn{2}{|l|}{ (1) } & \multicolumn{2}{|c|}{$\begin{array}{c}(2) \\
\text { Previous } \\
\text { CEO's CSR } \\
\end{array}$} & \multicolumn{2}{|c|}{$\begin{array}{c}(3) \\
\text { High/Low } \\
\text { CSR } \\
\end{array}$} \\
\hline CSR Net & $\begin{array}{c}0.007 \\
(0.013) \\
{[0.0007]}\end{array}$ & & $\begin{array}{c}0.009 \\
(0.018) \\
{[0.000]}\end{array}$ & & $\begin{array}{c}0.031 \\
(0.104) \\
{[0.003]}\end{array}$ & \\
\hline Interaction CSR Net - Negative Returns & $\begin{array}{l}-0.152 \\
(0.051) \\
{[-0.014]}\end{array}$ & $* * *$ & $\begin{array}{c}-0.112 \\
(0.065) \\
{[-0.009]}\end{array}$ & $*$ & $\begin{array}{c}-1.195 \\
(0.433) \\
{[-0.115]}\end{array}$ & $* *$ \\
\hline CSR (Change) & & & $\begin{array}{c}-0.024 \\
(0.034) \\
{[-0.002]}\end{array}$ & & & \\
\hline Interaction CSR (Change)- Negative Returns & & & $\begin{array}{c}-0.130 \\
(0.139) \\
{[-0.011]}\end{array}$ & & & \\
\hline Positive Returns & $\begin{array}{c}-0.003 \\
(0.199)\end{array}$ & & $\begin{array}{l}-0.223 \\
(0.216)\end{array}$ & & $\begin{array}{l}-0.066 \\
(0.238)\end{array}$ & \\
\hline Negative Returns & $\begin{array}{c}-1.151 \\
(0.224) \\
{[-0.108]}\end{array}$ & $* * *$ & $\begin{array}{c}-0.918 \\
(0.257) \\
{[-0.077]}\end{array}$ & $* * *$ & $\begin{array}{l}-0.668 \\
(0.333) \\
{[-0.064]}\end{array}$ & $* *$ \\
\hline Returns Volatility & $\begin{array}{c}0.197 \\
(0.053)\end{array}$ & $* * *$ & $\begin{array}{c}0.200 \\
(0.066)\end{array}$ & $* * *$ & $\begin{array}{c}0.171 \\
(0.061)\end{array}$ & $* * *$ \\
\hline Board Size & $\begin{array}{c}0.043 \\
(0.017)\end{array}$ & $* *$ & $\begin{array}{c}0.049 \\
(0.021)\end{array}$ & $* *$ & $\begin{array}{c}0.028 \\
(0.020)\end{array}$ & \\
\hline Independent Directors (\%) & $\begin{array}{c}0.479 \\
(0.259)\end{array}$ & & $\begin{array}{c}0.450 \\
(0.313)\end{array}$ & & $\begin{array}{c}0.331 \\
(0.293)\end{array}$ & \\
\hline CEO Age (log) & $\begin{array}{c}5.768 \\
(0.417)\end{array}$ & $* * *$ & $\begin{array}{c}6.527 \\
(0.477)\end{array}$ & $* * *$ & $\begin{array}{c}5.471 \\
(0.472)\end{array}$ & $* * *$ \\
\hline Retirement Age CEO & $\begin{array}{c}0.177 \\
(0.129)\end{array}$ & & $\begin{array}{c}0.238 \\
(0.138)\end{array}$ & $*$ & $\begin{array}{c}0.285 \\
(0.146)\end{array}$ & $* *$ \\
\hline Assets $(\log )$ & $\begin{array}{c}0.041 \\
(0.030)\end{array}$ & & $\begin{array}{c}0.137 \\
(0.038)\end{array}$ & $* * *$ & $\begin{array}{c}0.059 \\
(0.034)\end{array}$ & $*$ \\
\hline Book to Market Ratio & $\begin{array}{l}-0.367 \\
(0.166)\end{array}$ & $* *$ & $\begin{array}{l}-0.018 \\
(0.205)\end{array}$ & & $\begin{array}{l}-0.450 \\
(0.191)\end{array}$ & $* *$ \\
\hline Intercept & $\begin{array}{r}-26.442 \\
(1.788)\end{array}$ & $* * *$ & $\begin{array}{l}-32.964 \\
(2.346)\end{array}$ & $* * *$ & $\begin{array}{l}-25.026 \\
(2.058)\end{array}$ & $* * *$ \\
\hline $\begin{array}{l}\text { Number of observations } \\
\text { Year and Industry Fixed } \\
\text { Wald Test } \\
\text { Pseudo R2 }\end{array}$ & $\begin{array}{c}20,227 \\
\text { Yes } \\
323.45 \\
0.076\end{array}$ & $* * *$ & $\begin{array}{c}19,268 \\
\text { Yes } \\
439.60 \\
0.113\end{array}$ & $* * *$ & $\begin{array}{c}14,780 \\
\text { Yes } \\
316.73 \\
0.075\end{array}$ & $* * *$ \\
\hline
\end{tabular}


Table 3 - Panel B

Marginal effect of Corporate Social Responsibility on CEO Turnover Performance Sensitivity

This table analyzes the marginal effects of CSR Net on CEO Turnover. The dependent variable is CEO Turnover; our main variable of interest is Negative Returns. All variables are winsorized at the $1 \%$ and 99\% level. Standard Errors are clustered by firm and are reported in parenthesis. Margins are reported in square brackets. Model (1) is run over a subsample of observations in which the value of CSR Net is below 0, Model (2) is run over a subsample of observations in which CSR Net is 0 and, finally, Model (3) is run over a subsample of observations in which CSR Net is above 0 .

Levels of significance are indicated by: ${ }^{*} \mathrm{p}<0.10, * * \mathrm{p}<0.05, * * * \mathrm{p}<0.01$

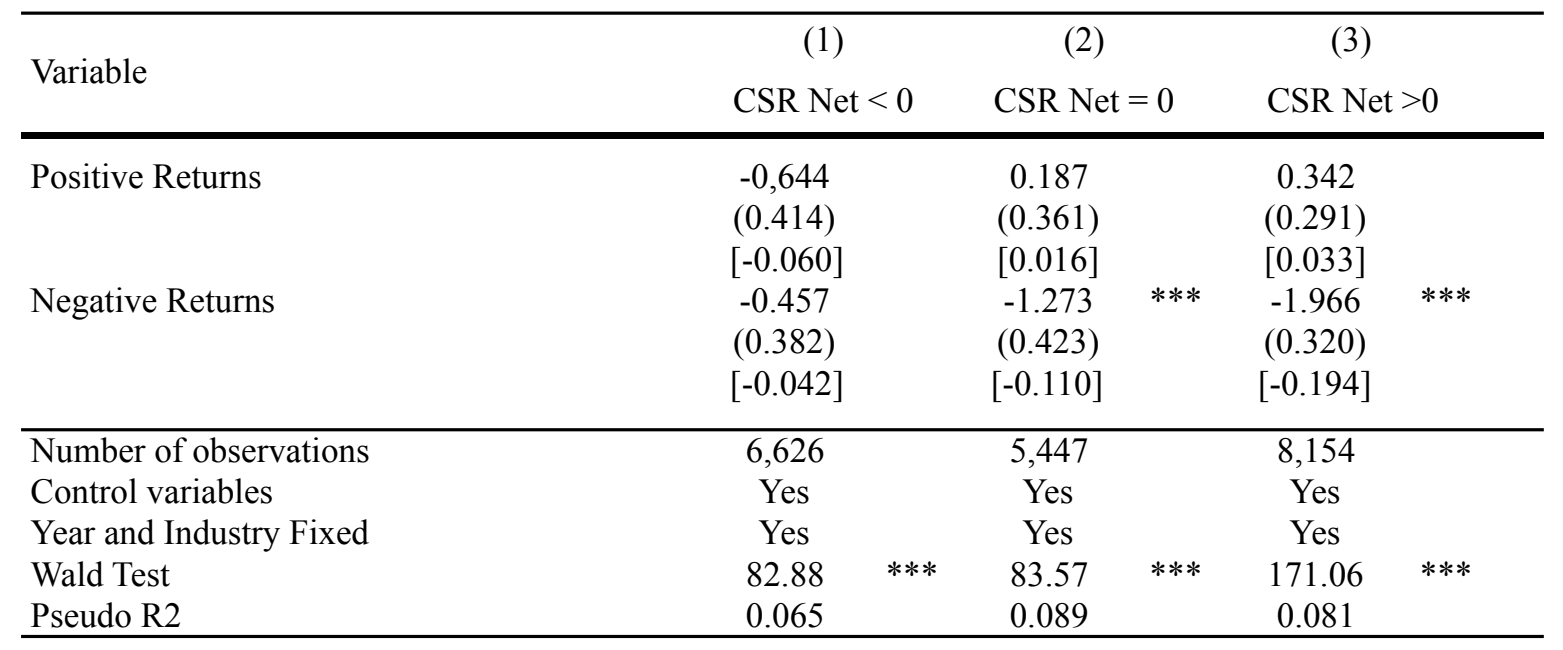


Table 4

Effect of CSR (Strength and Concerns) on CEO Turnover Performance Sensitivity

This table analyzes the determinants of CEO Turnover. The dependent variable is CEO Turnover; our main variables of interest are CSR Strengths, CSR Concerns and their interaction with Negative Returns. All variables are winsorized at the $1 \%$ and $99 \%$ level. Standard Errors are clustered by firm and are reported in parenthesis. Margins are reported in square brackets. Model (1) has CSR Strengths, Model (2) has CSR Concerns and Model (3) has both Strengths and Concerns. In Models (4) and (5) we replace CSR Strengths and Concerns with those of the previous CEO, independent of the current CEO's action, as well as examine the change in CSR from that of the previous CEO. We look at the interaction between the previous CEO's CSR Strength and Concerns and Negative Returns as well as the interaction between changes in Strengths and Concerns and Negative Returns.

Levels of significance are indicated by: $* \mathrm{p}<0.10, * * \mathrm{p}<0.05, * * * \mathrm{p}<0.01$

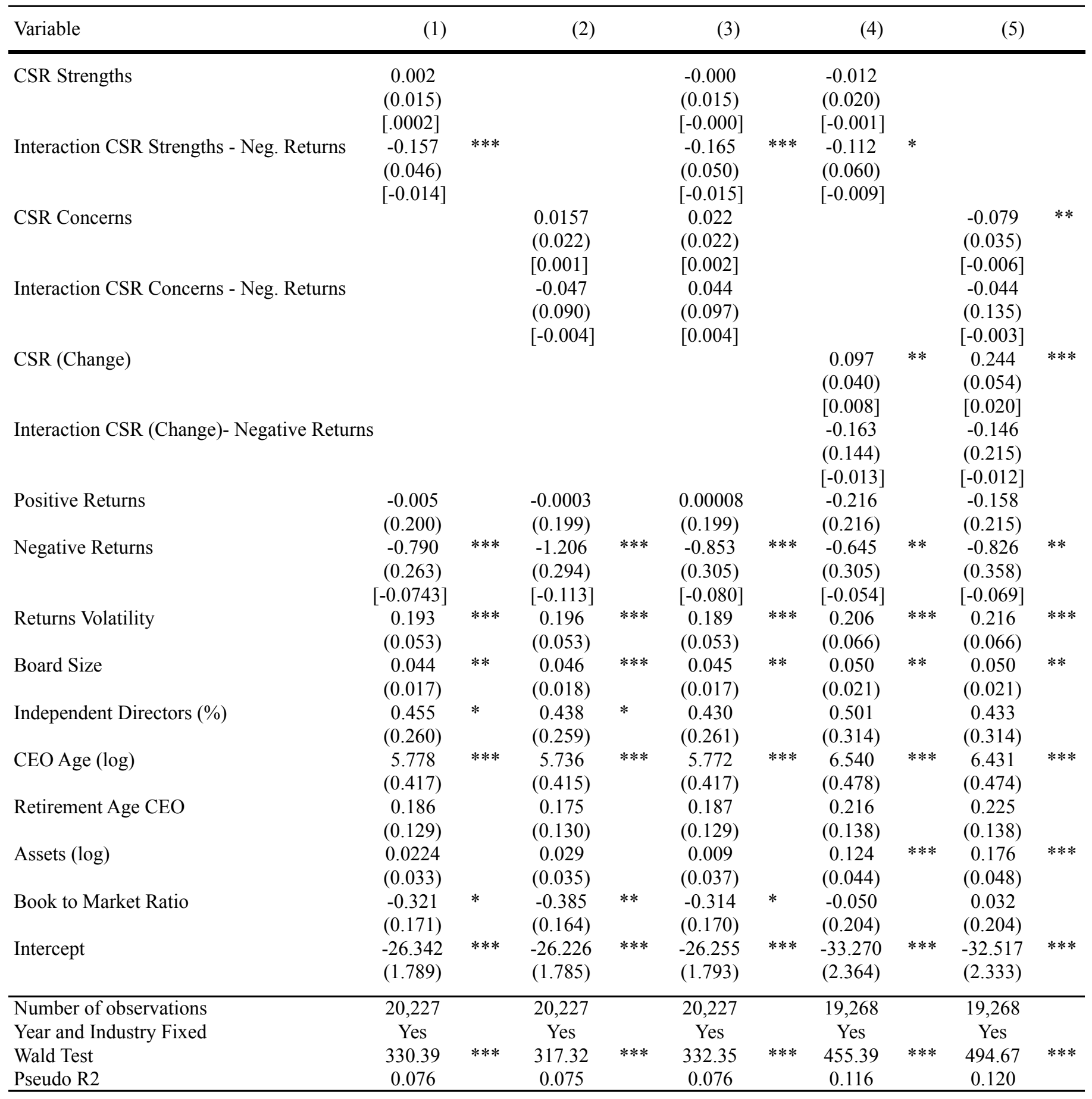




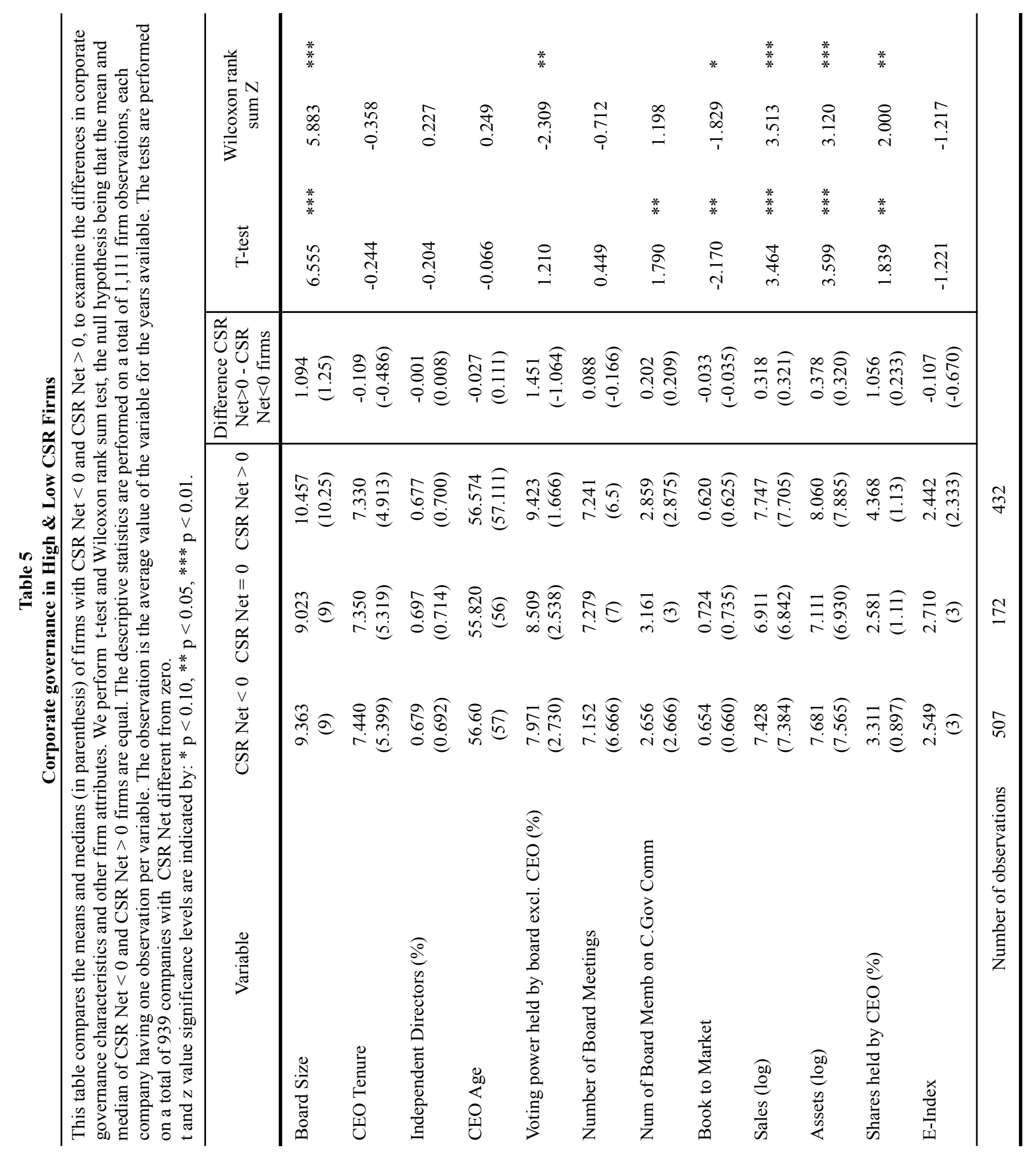


Table 6 - Panel A

Effect of Corporate Social Responsibility (Predicted and Residual) on CEO Turnover Performance Sensitivity

This table analyzes the determinants of CEO Turnover, with respect to the various dimensions of CSR. The dependent variable is CEO Turnover; our main variables of interest are the predicted and residuals of CSR Net, CSR Strengths, CSR Concerns and their interactions with Negative Returns. All variables are winsorized at the $1 \%$ and 99\% level. Standard Errors are clustered by firm and are reported in parenthesis. Margins are reported in square brackets.

Levels of significance are indicated by: ${ }^{*} \mathrm{p}<0.10,{ }^{* *} \mathrm{p}<0.05,{ }^{* * *} \mathrm{p}<0.01$

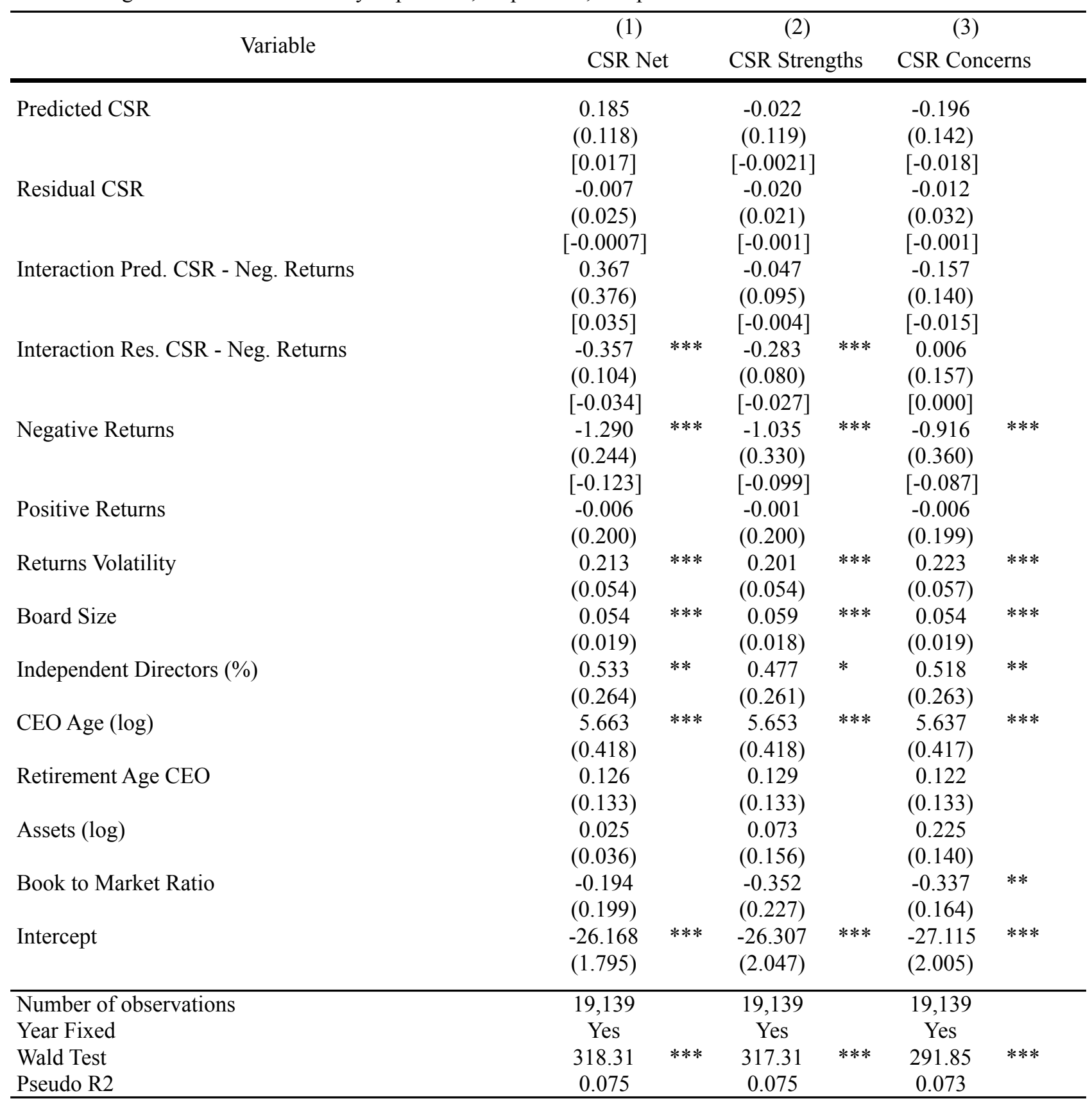


Table 6 - Panel B

Effect of Corporate Social Responsibility on CEO Turnover Performance Sensitivity by tenure

This table analyzes the determinants of CEO Turnover, which is the dependent variable. Our main variable of interest is the interaction between CSR and Negative Returns. All variables are winsorized at the 1\% and $99 \%$ level. Standard Errors are clustered by firm and are reported in parenthesis.

Margins are reported in square brackets. Model (1) is run over a subsample of observations in which CEO Tenure is below the median; Model (2) is run over the subsample of observation in which CEO Tenure is above the median.

Levels of significance are indicated by: $* \mathrm{p}<0.10,{ }^{* *} \mathrm{p}<0.05,{ }^{* * *} \mathrm{p}<0.01$
(1)
(2)

Variable

Low CEO Tenure High CEO Tenure

\begin{tabular}{|c|c|c|c|c|}
\hline CSR Net & $\begin{array}{c}-0.028 \\
(0.021) \\
{[-0.002]}\end{array}$ & & $\begin{array}{c}0.006 \\
(0.018) \\
{[0.0007]}\end{array}$ & \\
\hline Interaction CSR Net - Negative Returns & $\begin{array}{c}-0.206 \\
(0.065) \\
{[-0.014]}\end{array}$ & $* * *$ & $\begin{array}{c}-0.061 \\
(0.086) \\
{[-0.007]}\end{array}$ & \\
\hline Positive Returns & $\begin{array}{l}-0.329 \\
(0.301)\end{array}$ & & $\begin{array}{c}0.165 \\
(0.261)\end{array}$ & \\
\hline Negative Returns & $\begin{array}{c}-1.439 \\
(0.334) \\
{[-0.104]}\end{array}$ & $* * *$ & $\begin{array}{c}-0.942 \\
(0.294) \\
{[-0.108]}\end{array}$ & $* * *$ \\
\hline Returns Volatility & $\begin{array}{c}0.417 \\
(0.079)\end{array}$ & $* * *$ & $\begin{array}{c}0.061 \\
(0.071)\end{array}$ & \\
\hline Board Size & $\begin{array}{c}0.059 \\
(0.030)\end{array}$ & & $\begin{array}{c}0.033 \\
(0.021)\end{array}$ & \\
\hline Independent Directors (\%) & $\begin{array}{l}-0.290 \\
(0.395)\end{array}$ & & $\begin{array}{c}1.000 \\
(0.340)\end{array}$ & $* * *$ \\
\hline CEO Age $(\log )$ & $\begin{array}{c}6.549 \\
(0.696)\end{array}$ & $* * *$ & $\begin{array}{c}4.914 \\
(0.559)\end{array}$ & $* * *$ \\
\hline Retirement Age CEO & $\begin{array}{c}0.324 \\
(0.266)\end{array}$ & & $\begin{array}{c}0.124 \\
(0.147)\end{array}$ & \\
\hline Assets $(\log )$ & $\begin{array}{c}-0.030 \\
(0.045)\end{array}$ & & $\begin{array}{c}0.100 \\
(0.040)\end{array}$ & $* *$ \\
\hline Book to Market Ratio & $\begin{array}{l}-0.513 \\
(0.252)\end{array}$ & $* *$ & $\begin{array}{l}-0.409 \\
(0.225)\end{array}$ & \\
\hline Intercept & $\begin{array}{l}-28.567 \\
(2.926)\end{array}$ & $* * *$ & $\begin{array}{l}-23.604 \\
(2.389)\end{array}$ & $* * *$ \\
\hline $\begin{array}{l}\text { Number of observations } \\
\text { Year and Industry Fixed } \\
\text { Wald Test } \\
\text { Pseudo R2 }\end{array}$ & $\begin{array}{l}10,121 \\
\text { Yes } \\
224.63 \\
0.108\end{array}$ & $* * *$ & $\begin{array}{c}10,106 \\
\text { Yes } \\
122.46 \\
0.055\end{array}$ & $* * *$ \\
\hline
\end{tabular}


Table 7 - Panel A

Difference in Changes in CSR between Turnover and Non-Turnover Years

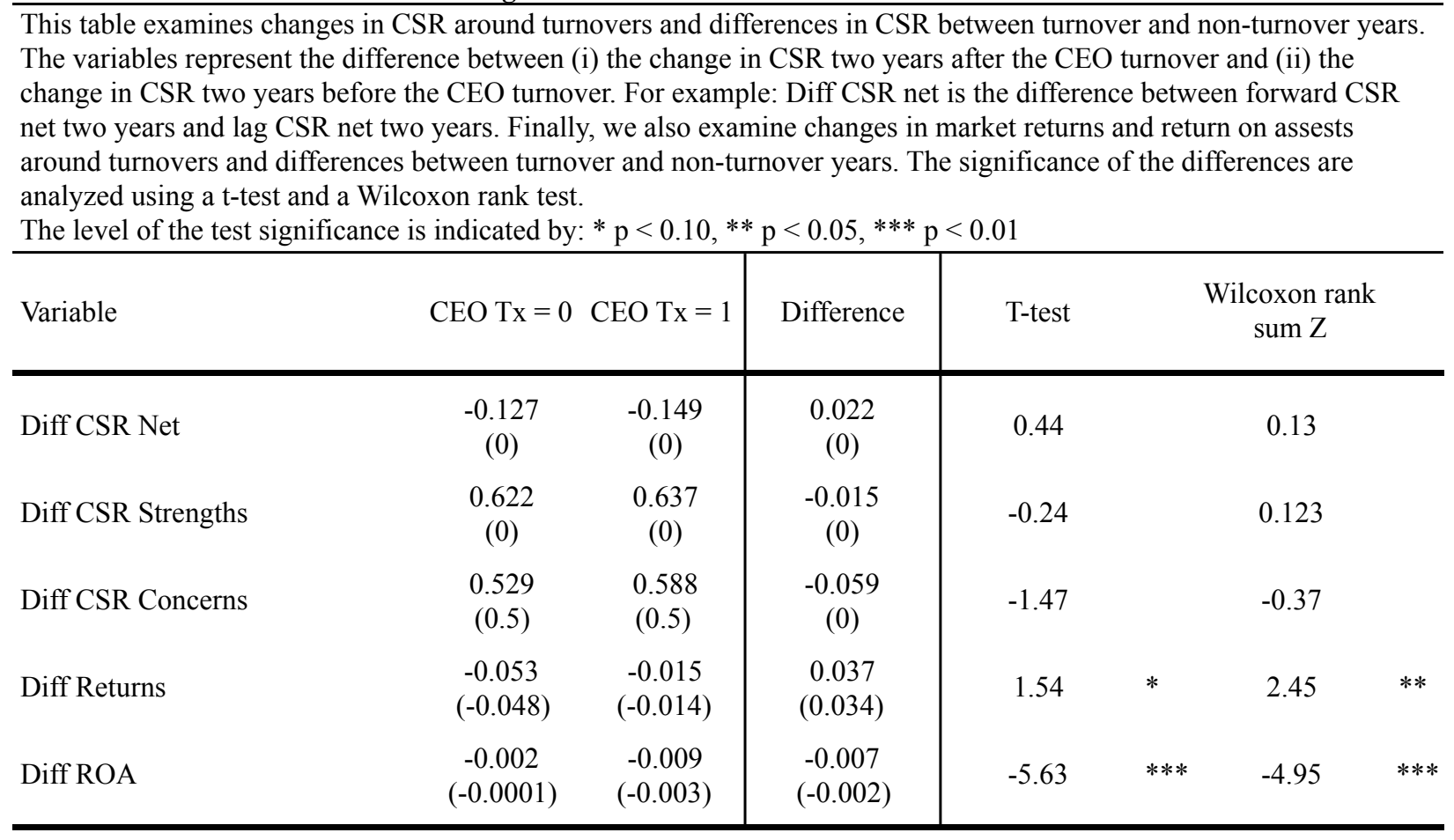




\section{Table 7 - Panel B}

\section{Determinants of Change in CSR (Net, Strengths, Concerns)}

This table examines the determinants of changes in CSR (Net, Strengths, Concerns) around turnovers. We run a logistic regression of positive changes in CSR. Our dependent variable is an indicator variable of changes in CSR set to one in cases where the change in CSR is greater than zero and zero otherwise. We measure the change in CSR as the difference between the two-year average lead and two-year average lag. The dependent variable is the change in CSR Net in Model (1); the change in CSR Strengths in Model (2); the change in CSR Concerns in Model (3). Our main variables of interest are: Negative Returns (ind), which is and indicator variable set to one if returns are negative and zero otherwise; CEO Turnover and Neg. Ret. (ind) - CEO Turnover, which is the interaction between the two. Both models are run with change in log assets, industry, and year fixed effects. Standard Errors are clustered by firm and are reported in parenthesis.

Levels of significance are indicated by: $* \mathrm{p}<0.10, * * \mathrm{p}<0.05, * * * \mathrm{p}<0.01$

(1) (2) (3)

Variable

CSR Net CSR Strengths CSR Concerns

Negative Returns (ind)

$\begin{array}{cccccc}0.144 & * * & 0.029 & & -0.218 & * * * \\ (0.054) & & (0.052) & & (0.054) & \\ 0.038 & & 0.039 & & 0.050 & \\ (0.116) & & (0.112) & & (0.114) & \\ -0.190 & & 0.092 & & 0.197 & \\ (0.161) & & (0.157) & & (0.159) & \\ -0.327 & & 0.605 & * * & 1.14 & * * * \\ (0.314) & & (0.302) & & (0.322) & \end{array}$

CEO Turnover

9.176

Number of observations

Year and Industry Fixed

Wald chi2

9.176
Yes

9.176

Yes

9.176

Pseudo R2

33.45

0,012

31.48

Yes

*** $\quad 31.48$

$* * *$

122

0.036 